UDK $81.111+811.161 .2 ’ 2 / 4$

DOI $10.15421 / 462008$

\title{
LINGUISTIC ATTRACTION OF CHRLES DICKENS' BOOKS
}

O. Panchenko

Doctor of Philology, Professor, Head of Department of translation and linguistic training of foreigners, Oles Honchar Dnipro National University epanchenko2017@gmail.com orcid.org/0000-0003-2217-5613

Introduction. The relevance of this topic is determined by the fact that really high-quality works of any style and genre are always attractive, which is why they deserve the reader's attention. This attraction is achieved to a large extent through the use of certain language and speech tools: lexical, syntactic, stylistic and so on. We consider that we can talk about universal and individual means of creating an attraction or their unique combination in the work of an author.

The problem of attraction is studied by such researchers as O. Griva (Griva, 2014), V. Grigoriev (Grigoriev, 1975), I. Kryvko (Kryvko, 2010), M. Makovsky (Makovsky, 1971), E. Naugolnykh (Naugolnykh), 2018), Yu. Poltavets (Poltavets, 2012), T. Filchuk (Filchuk, 2003), I. Frinberg (Frinberg, 2006) and others, who investigated the attraction between parts of a word, between words, between parts of a sentence or as an element technique of a particular author. But the linguistic attraction of Charles Dickens's work, as far as we know, has not yet been the subject of special research.

The goal we set in this paper is to identify the lexical and stylistic means of achieving attraction that are typical of Charles Dickens's novels. To achieve this goal, we consider it appropriate to solve the following tasks: to define the concept of attraction of a work of art; to accumulate factual material selected from the novels of Charles Dickens; to classify the found ways of acquiring attraction

Methods and methodology of investigation. The purpose and objectives of the paper led to the use of comprehensive methods involving general scientific methods, each of which involves procedures aimed at solving specific research problems, in particular the method of continuous sampling - to identify fragments of texts that may be perceived as attractive; classification method for systematization of linguistic means of creating attraction; functional analysis - to identify the role of these attractive fragments; quantitative method - to establish the frequency of certain attractive means.

Results and discussion. The material of our study was 5 novels by Charles Dickens ("Posthumous Papers of Pickwick Club", "Life and Adventures of Nickolas Nickleby", "Little Dorrit", "Great Expectations", "Our Mutual Friend"), which were once extremely popular among readers and still remain the most striking examples of classical English literature of the nineteenth century.

Leaving aside the literary analysis of Dickens's work, let us turn our attention to the linguistic means that have made his works so interesting to the reader, in other words, attractive.

The concept of "attraction" is used in various fields of scientific activity, including exact and humanitarian disciplines including linguistics; different researchers interpret and use it in their own way. In traditional linguistics, the term "attraction" has a more formal essence, reflecting the internal relations between language units, for example, in the "Dictionary of Linguistic Terms" by O. Akhmanova definition is defined as "a change in the form of elements of expression towards greater similarity with other elements" (Akhmanova, 2004: 69-70) and the following types of attraction are distinguished: temporal attraction, modal (assimilation of mode of action), relative, negative, paronymic (same as folk etymology), by case (antiptosis), by genus (Akhmanova, 2004). The term "paronymic attraction" is interpreted in a narrow sense: it is identified with folk 


\section{Ukrainian sense. 2020. ISSN 2313-4437}

etymology, but it is one of the manifestations of linguistic attraction, one of the aspects of its functioning.

The phenomenon of attraction was studied by M. Makovsky, who in the late 60's - early 70 's of the twentieth century developed and substantiated the linguistic concept - the theory of lexical attraction, described the inner nature, mechanism of development and synchronous existence of the lexical-semantic system in its various aspects. According to this theory, the presence of this word (or words), endowed with a strictly defined meaning (or several specific meanings) in a language (macrostructure) or language layer (microstructure), is determined by a certain lexical environment, i.e. a set of lexical units, within which the word exists at a particular stage of language development; a change in the composition or properties of individual lexical units entails a change in the composition of the corresponding environment and the properties of its constituent components (Makovsky, 1971: 48).

V. Grigoriev analyzes in detail the phenomenon of paronymic attraction, which, by his definition, is a system of "paradigmatic relations between similar in terms of expression multirooted words (not related in the synchrony of poetic language signs of explicit derivational proximity)" (Grigoriev, 1975: 264), which is realized "in specific texts by converging paronyms in the language chain, due to which there are various effects of semantic proximity or, conversely, the opposition of paronyms" (Grigoriev, 1975: 264).

In more contemporary studies on the phenomenon of attraction the text analyses predominate. T. Filchuk considers the concept of language attraction as the core of the modern mental system, which forms an associative plan of different types of texts and concludes that language attraction is a kind of language universal. The phenomenon of linguistic attraction has different plans: a philosophical plan that determines the associative-symbolic nature of language in its phenomenological and functional sense, in terms of its perception, and a functional plan that is realized in sound, verbal, figurative components that make up text categories, in accordance at the level of "visible" forms and meanings (Filchuk, 2003: 48).

Thus, the analysis of the available linguistic literature on the problems of attraction allows us to say that there is a traditional, so to speak, "intralinguistic" understanding of attraction, when it is considered as a mechanical phenomenon, "attraction" to each other individual elements of language (sounds, roots, words, etc.). In other works, linguistic attraction is perceived as an external phenomenon, the "attraction" of each other's linguistic work and the reader. In this sense, based on the analysis of the material devoted to the understanding of the term attraction, we can offer our definition of its variety, such as linguistic attraction.

Linguistic attraction is the focus of the influence on its reader (listener), which determines the reader's interest in the text, according to it, the individual increases (or in its absence decreases) interest in a work of art.

According to our observations, the most typical means of creating linguistic attraction of the works of Charles Dickens, which largely make his works easily recognizable, are:

1) irony as the most common stylistic device;

2) a variety of puns, which covers the levels of sound, morphemes, words, interspersed with foreign or altered units, etc.;

3) individualization of the character's speech at the level of vocabulary, grammar, creation of specific lexical and syntactic units.

Dickens discovered through irony more than historians could ever find with a direct story. Dickens uses all kinds of irony: verbal, dramatic and situational, and their consequences are part of what makes his work not only colorful, but also extremely attractive. Irony has been and remains one of the writer's most powerful tools for subtly describing characters, society and the era, for sharp criticism of social unrest and political crimes, injustice, but is also a pleasant means to offer advice, correct a rejected judgment, or support and revive the weakened, beliefs (Colebrook, 2004).

A striking example of Dickens's irony is the following fragment $M r$ Squeers's appearance was not prepossessing. He had but one eye, and the popular prejudice runs in favour of two. The eye he had, was unquestionably useful, but decidedly not ornamental: being of a greenish grey, and 


\section{Ukrainian sense. 2020. ISSN 2313-4437}

in shape resembling the fan-light of a street door. Наружность мистера Сквирса не располагала в его пользу. У него был только один глаз, а в результате обычного предрассудка предпочтение отдается двум. Глаз его был бесспорно полезен, но решительно некрасив - окрашенный в зеленовато-серый цвет и напоминающий своим разрезом веерообразное оконще над парадной дверью.

The author is supposed to be neutral in his attitude to the character, but with a few words he creates a deadly ironic image, which is remembered after the first acquaintance, and the reader no longer expects anything good from this character.

We observe verbal-situational irony in the example This part of the conversation was rather unintelligible; but popular rumour in the neighbourhood asserted that Mr Squeers, being amiably opposed to cruelty to animals, not infrequently purchased for by consumption the bodies of horned cattle who had died a natural death; possibly he was apprehensive of having unintentionally devoured some choice morsel intended for the young gentlemen. Эта часть диалога была, пожалуй, неудобопонятна, но в округе ходила молва, что мистер Сквирс, будучи, по мягкосердечию, противником жестокого обращения с животными, нередко покупал для кормления своих питомцев туши рогатого скота, умершего естественной смертью; быть может, он испугался, что неумышленно проглотил какой-нибудь лакомый кусок, предназначавшийся для юных джентльменов.

The juxtaposition of the character's "kindness" to animals and his criminal indifference to the school boys continues the author's murderous irony of Mr. Squires, and in his person, of the then-widespread cruelty to children who were sent to the odious schools of Yorkshire under Dickens.

Another example of vivid situational irony is The page left it; but if ever an Alphonse carried plain Bill in his face and figure, that page was the boy. Альфонс вышел; но если у какогонибудь Альфонса было ясно написано на лище “Билл”, то именно таким мальчуганом был этот паж.

The irony is that in English society, the name was firmly entrenched in one stratum of the population, the services of a simple boy were cheaper than a child from a noble family, so his mistress is trying to save money by a resounding name.

A striking feature of Dickens's style is a variety of puns. As an example of a play on words at the sound level, consider the famous "instruction" that Mrs. General from the novel "Little Dorrit" gives to her pupils, explaining to them with what facial expression a noble girl should come into the living room to look attractive: Papa, potatoes, poultry, prunes and prism are all very good words for the lips. Translated linguistic play on words. beginning with the labial sound $P$, transmitted as follows: Слово "папа" придает изящную форму губам. Папа, пчела, пломба, плющ и пудинг - очень хорошие слова для губ; в особенности плющ и пудинг. There is another analogical variant of translation: Слово папа придает изящную форму губам. Папа, помидор, птица, персики и призмы - прекрасные слова для губ, особенно персики и призмыл.

A pun on the morpheme level is also widely used: "Never postpone business", is the very first lesson we instill into our commercial pupils... "Never", repeated Master Belling. '...' 'P', suggested Nicholas, good-naturedly. 'Perform--business!' said Belling. 'Never-perform-business!" "Никогда не уклоняйтесь от дела!" - вот первое правило, которое мы внушаем нашим ученикам, изучаюшим коммеричию... Никогда не - начал юный Беллинг. У... - добродушно подсказал Николас. - Увлекайтесь... делом! - сказал юный Беллинг. Никогда... не увлекайтесь... делом!" In this case, the boy tries to form the desired verb at the prompt, but, keeping only its initial part, names the word with the opposite meaning. Instead of the English words postpone and perform, the translator successfully used the words уклоняться and увлекаться.

Another interesting passage saturated with linguistic game at the level of morpheme is available in the novel "Our mutual friend". Lawyer Lightwood, ducking at him with a servile air, "I am a man as gets my living, and as seeks to get my living, by the sweat of my brow. Not to risk being done out of the sweat of my brow, by any chances, I should wish afore going further to be 


\section{Ukrainian sense. 2020. ISSN 2313-4437}

swore in". - "I am not a swearer in of people, man". - The visitor, clearly anything but reliant on this assurance, doggedly muttered "Alfred David". - "Is that your name?" asked Lightwood. "My name?" returned the man. "No; I want to take a Alfred David". (Which Eugene, smoking and contemplating him, interpreted as meaning Affidavit). "I tell you, my good fellow", said Lightwood, with his indolent laugh, "that I have nothing to do with swearing". - "He can swear AT you", Eugene explained; "and so can I. But we can't do more for уои”. Адвокат Лайтвуд, - с раболепным поклоном, - я человек, который добывает себе пропитание в поте лииа. Хотелось бы мне прежде всего прочего, чтобы вы привели меня к присяге, а то как бы мне случайно не лишиться того, что я зарабатываю в поте лица. -Я этим не занимаюсь, любезный. Посетитель, явно не доверяя этому заявлению, упрямо пробормотал: - Альфред Дэвид. - Это вас так зовут? - спросил Лайтвуд. - Меня? - переспросил гость. - Нет, мне надо, сами знаете: “Альфред Дэвид”. Юджин, который курил, разглядывая гостя, объяснил, что тот желает дать присягу. - Я же вам говорю, мой любезный, что не имею никакого отношения к присяге и клятве, - лениво усмехнувшись, сказал ему Лайтвуд. - Он может вас проклясть, - объяснил Юджин, - и я тоже. А больше мы ничего для вас сделать не можем. The similarity of Alfred David's name and the name of the oath is not translated, but the English postpositions are successfully compensated with the prefix - клясться - проклясть.

In another example from the same work, the words-participants of the game differ in one morpheme - a suffix. He is a very strange man,' said Lizzie, thoughtfully. 'I wish he was so very strange a man as to be a total stranger,' answered the sharp little thing. Какой странный человек, - задумчиво проговорила Лиззи. - Подальше бы от него. Лучше бы он был иностранный, - сказала эта язвительная юная особа.

One more well-known method of creating an attractive pun is usage of rhyme which can be illustrated by the example from the novel abovementioned. Impertinent girl! Minx!' said Mrs Wilfer, with dread severity. 'I don't care whether I am a Minx, or a Sphinx,' returned Lavinia, coolly, tossing her head...' Наглая девчонка! Мегера! - произнесла миссис Уилфер с поистине угрожающей суровостью. - Мегера я или пантера,- тряхнув головкой, преспокойно ответила Лавиния...

Word play at the phrase level in the case of an unexpected combination is an interesting and attractive tool, being in line with other words in the whole sentence, as exemplified by a Frenchspeaking cat in the novel The Life and Adventures of Nicholas Nickleby: 'Talk, miss! It's enough to make a Tom cat talk French grammar, only to see how she tosses her head,' replied the handmaid. 'She DOES toss her head,' observed Miss Squeers, with an air of abstraction. Болтаю, мисс! Kот и тот заболтает по-франиузски, чтобы только посмотреть, как она трясет головой,отозвалась горничная. - Она и в самом деле трясет головой - с рассеянным видом заметила мисс Сквирс.

Sometimes we meet the pun due to foreign inclusion into the text: What's the water in French, sir?''L'EAU,' replied Nicholas.'Ah!' said Mr Lillyvick, shaking his head mournfully, 'I thought as much. Lo, eh? I don't think anything of that language - nothing at all.' Kaк noфраниузски вода, сэр? - L'eau, - ответил Николас. - Вот как! - сказал мистер Лиливик, горестно покачивая головой. - Я так и думал. Ло? Я невысокого мнения об этом языке, совсем невысокого. We believe that this word play can only be conveyed through certain footnotes. The game is that the French word "water" sounds similar to the English word "law"; Mr. Lillyvick, who collects the money for water, is probably abusing these funds, so the consonance of the words is unpleasant for him.

One of the most striking features of Dickens's work is the individualization of the character's speech, which allows you to distinguish this or that character from others immediately. Note that this individualization applies to minor characters and, according to our observations, about three times more often than negative characters.

This individualization can be observed at the level of words, such as hyperbole and curses in Mr. Mantalini's speech. ("Nicholas Nickleby"): 'My life,' said Mr Mantalini, 'what a demd devil of a time you have been!' 'Then what a doubly demd infernal rascal that footman must be, my soul,' 


\section{Ukrainian sense. 2020. ISSN 2313-4437}

remonstrated Mr Mantalini. Жизнь моя, - сказал мистер Манталини, - как дьявольски долго ты не приходила! ...В таком случае, душа моя, каким же вдвойне дьявольским негодяем должен быть этот лакей...

Mr Edmund Sparkler and Jeremy Flintwinch also have their typical words (Little Dorrit) correspondingly 'a doosed fine gal--well educated too--with no biggodd nonsense about her'. "ремиленькая канашка - и хорошо воспитана - без разных там фиглей-миглей", or in another variant "без всяких этаких глупостей" та уои тиst have a dose - "И я тебя полечу, уж я тебя полечу". The second variant of translation is - "я тебе закачу пориию, хорошую пориию".

Common phonetic and grammatical errors are a common means of individualizing a character's speech, which emphasizes their social position. So, in the novel "Nicholas Nickleby" one of the brightest "linguistically colored" characters is John Brody, an uneducated merchant who says: 'I say, coot awa',' repeated John, hastily. 'Dost thee know where thee livest? Thee dost?_Weel. Are yon thy clothes, or schoolmeasther's?' 'Mine,' replied Smike, as the Yorkshireman hurried him to the adjoining room, and pointed out a pair of shoes and a coat which were lying on a chair.

The wrong usage of pronouns or verbs in the original plays an important role and is compensated by lexical means during translation: Я тебе говорю - удирай! - быстро повторил Джон. - Ть знаешь, где живешь? Знаешь? Ладно. Это твой сюртучишко или учительский? - Мой, - ответил Смайк, когда йоркширеи увлек его в соседнюю комнату и указал ему на башмаки и сюртук, лежавшие на стуле.

A special individualized unit is wellerism - a statement that covers a constant expression, the situation and the author of the first part, the mention of which completely changes the meaning of wellerism. The term comes from the name of one of the heroes of Charles Dickens' novel "Posthumous Notes of the Pickwick Club" Samuel Weller (in English writing Weller). Here are some examples. That's what I call a self-evident proposition, as the dog's-meat man said, when the housemaid told him he warn't a gentleman - Это я называю истиной, не требуюшей доказательств, как заметил продавеи собачьего корма, когда служанка, сказала ему, что он не джентльмен; Fine time for them as is well wropped up, as the Polar Bear said to himself, ven he was practising his skating - Славная погода для тех, кто тепло укутан, как сказал самому себе полярный медведь, скользя по льду.

In order to reach the individual speech (of a child or a foreigner as in the following examples) sounds typical for this or that speech are used: And then Mrs Veneering - for the Lady Tippins's winning wiles are contagious - folds her hands in the manner of a supplicating child, turns to her left neighbour, and says, 'Tease! Pay! Man from Tumwhere!' И тут миссис Вениринг - так заражающе действуют обольстительные кривлянья леди Типпинз, - сложив руки на манер просящего ребенка, обращается к соседу слева и шепелявит: - Плосу вас! Позалуста! Пло иеловека ниоткуда! 'A kiss for the boofer lady.' Поиелуй касивую леди (Our Mutual Friend).

In translation these peculiarities are compensated by lexical means. The foreign gentleman found it, without doubt, enormement riche. 'Enormously Rich, We say,' returned Mr Podsnap, in a condescending manner. 'Our English adverbs do Not terminate in Mong, and We Pronounce the "ch" as if there were a " $t$ " before it. We say Ritch.' 'Reetch,' remarked the foreign gentleman. Иностранный гость согласился, что он очень богат, без сомнения, епогтетеnt riche. - Mbl говорим по-другому, - пояснил мистер Подснеп снисходительным тоном. - Наши наречия не оканчиваются на “ман”, и произносим мы не так, как франиузы. Мы говорим: “богат”. Бо-га-атт, повторил за ним иностранный гость.

From the above examples it is clear that the author uses a diverse palette of linguistic means of the character's speech individualization.

Conclusions. As time has proven, the works of Charles Dickens were and remain attractive to any reader. Analysis of the linguistic means of achieving this attraction shows that they can be classified as follows: irony as the most common stylistic device inherent in the work of Dickens; various play on words at the level of sound (including rhyme), morphemes, words, phrases; individualization of the character's speech, which is carried out with the help of certain words or 


\section{Ukrainian sense. 2020. ISSN 2313-4437}

syntactic constructions. Prospects for further research we see in the analysis of the preservation or loss of these means of attraction during translation.

\section{REFERENCES}

Ahmanova, O. S. (2004). Slovar' lingvisticheskih terminov [Dictionary of Linguistic Terms]. Moscow: URSS; Editorial URSS [In Russian].

Bogachevs'ka, L. O. (2007). Charlz Dikkens i ukrains'ka literatura: problemi recepcii ta tipologii [Charles Dickens and Ukrainian Literature: Problems of Reception and Typology]. Candidate's thesis. Kyiv [In Ukrainian].

Griva, O. V. (2014). Mezhlichnostnaya attrakciya i ee determiniruyushchie faktory [Interpersonal Attraction and its Determining Factors]. Sovremennaya psihologiya: materialy II Mezhdunar. nauch. konf. [Modern Philology: Materials of the II International Seminar]. Perm': Merkurij [In Russian].

Grigor'ev, V. P. (1976). Paronimicheskaya attrakciya v russkoj poezii igor'ev [Paronymic Attraction in Russian Poetry]. Moscow: Nauka [In Russian].

Krivko, I. P. (2010). Specifika sinonimicheskoj attrakcii v leksikone individa: sinergeticheskij podhod [Specifics of Synonymic Attraction in the Lexicon of Individuum; Synergetic approach]. Candidate's thesis. Kursk [In Russian].

Makovskij, M. M. (1971). Teoriya leksicheskoj attrakcii (opyt funkcional'noj tipologii leksiko-semanticheskih sistem) [Theory of Lexical Attraction (experience of functional typology of lexico-semantic system]. Moscow: Nauka [In Russian].

Naugol'nyh, E. A. (2018). Attrakciya kak element tekhniki Dzh. Dzhojsa v romane "Pominki po Finneganu" [Attraction as Element of J.Joyce Technique in the Novel "Finnegans Wake"]. Voronezh: Voronezhskiy Gosudarstvennyi Universitet [In Russian].

Poltavec', Yu. S. (2012). Istoriya ta vzhivannya termina "atrakciya” v movoznavchij tradicii [History and Usage of Term "Attraction" in Linguistic Tradition]. Mariupol [In Russian].

Fil'chuk, T. F. (2003). Yazykovaya attrakciya $v$ razlichnyh diskursivnyh proyavleniyah [Language Attraction in Various Discursive Manifestations]. Candidate's thesis. Kharkiv [In Russian].

Frishberg, I. D. (2006). Kognitivnyj aspekt sinonimicheskoj attrakcii glagol'nyh nominacij: na materiale anglijskogo i russkogo yazykov [Cognitive Aspect of Synonymic Attraction of Verb Nomination]. Candidate's thesis. Chelyabinsk [In Russian].

\section{Анотація}

Постановка проблеми. Актуальність теми визначається тим, щз дійсно високоякісні твори будь-якого стилю та жанру завжди є атрактивними, саме тому вони заслуговують на увагу читача. Цю атракиію досягнуто здебільшого завдяки використанню тих чи тих мовних та мовленнєвих засобів: лексичних, синтаксичних, стилістичних тощо. Уважаємо, щзо можна говорити про універсальні та індивідуальні засоби створення атракиії або їх своєрідне поєднання у творчості того чи того автора. Проблема атракиї вивчається такими дослідниками, як О. Грива, В. Григор'єв, І. Кривко, М. Маковський, Є. Наугольних, Ю. Полтавець, Т. Фільчук, І. Фрінберг та ін., які вивчали атракцію між частинами слова, між словами, між частинами речення або як елемент техніки того чи того автора. Утім, лінгвістична атракиія творчості Чарлза Діккенса ще не була предметом спеціального дослідження.

Мета статmi - визначення лексичних та стилістичних засобів досягнення атракції, що є характерними для романів Ч. Діккенса. Для досягнення цієєї мети вважаємо доцільним вирішити такі завдання: визначити поняття атракиї художнього твору; акумулювати фактичний матеріал, відібраний з романів Ч. Діккенса; класифікувати знайдені способи досягнення атракиії.

Методи дослідження. Мета й завдання роботи зумовили застосування комплексної методики із залученням загальнонаукових методів, у межах кожного з яких задіяні 


\section{Ukrainian sense. 2020. ISSN 2313-4437}

прочедури, спрямовані на вирімення конкретних дослідницьких завдань, зокрема застосовані метод суиільної вибірки - для виокремлення фрагментів текстів, щчо можуть сприйматися як атрактивні; класифікаційний метод - для систематизації лінгвальних засобів створення атракиії; функиійний аналіз - для виявлення ролі зазначених атрактивних фрагментів; кількісний метод - для встановлення частотності тих чи тих атрактивних засобів.

Основні результати дослідження. Ми визначаємо лінгвістичну атракцію як спрямування твору на його читача (слухача), яка зумовлює інтерес читача до тексту, відповідно до неї в індивіда підвищується (або за ї̈ відсутності знижується) інтерес до того чи того художнього твору. За нашими спостереженнями, найхарактернішими засобами створення лінгвістичної атракиії творів Ч. Діккенса, які значною мірою роблять його твори легко впізнаваними, є такі: 1) іронія як найпоширеніший стилістичний засіб; 2) різноманітна гра слів, щзо охоплює рівні звука, морфеми, слова, яскравих вкраплень іншомовних чи змінених одинищь тощо; 3) індивідуалізаџія мовлення персонажу на рівні лексики, граматики, створення специифічних лексико-синтаксичних одиниць.

Висновки і перспективи. Як доведено часом, твори Ч. Діккенса були й залишаються привабливими, атрактивними для будь-якого читача. Аналіз лінгвальних засобів досягнення иієї атракиії свідчить про те, щзо їх можна класифікувати в такий спосіб: іронія як найпоширеніший стилістичний прийом притаманний творчості Ч. Діккенса; різноманітна гра слів на рівні звука (зокрема й рими), морфеми, слова, словосполучення; індивідуалізація мовлення персонажа, яку здійснено за допомогою певних слів або синтаксичних конструкцій. Перспективи подальшого дослідження вбачаємо в аналізі збереження або втрати згаданих засобів атракиї під час перекладу.

Ключові слова: атракція, гра слів, іронія, індивідуалізація мовлення.

\section{Abstract}

Background. The relevance of the theme is determined by the fact that really high quality works of any style and genre are always attractive, which is why they deserve the attention of the reader. This attraction is achieved to a great extent due to the use of certain linguistic and speech means: lexical, syntactic, stylistic, etc. We consider that it is possible to speak about universal and individual means of creating attraction or their peculiar combination in the creativity of a particular author. The problem of attraction has been studied by such researchers as O. Gryva, V. Grigoriev, I. Kryvko, M. Makovsky, E. Naugolnykh, Y. Poltavets, T. Filchuk, I. Frinberg and others, who considered the attraction between word elements, between words, between parts of a sentence, or as an element of the technique of a particular author. But the linguistic attraction of Charles Dickens's work has not yet been the subject of special study.

The purpose is to identify lexical and stylistic means of attaining attraction that are typical of Charles Dickens' novels. In order to achieve this, we consider it appropriate to solve the following tasks: to define the concept of attraction of a work of art; to accumulate factual material selected from the novels of $C$. Dickens; to classify the found ways of reaching the attraction.

Methods. The purpose and objectives of the work have led to the use of a comprehensive methodology involving the use of general scientific methods, within which procedures aimed at solving specific research problems, in particular the continuous sampling method, are used - to isolate fragments of texts that can be perceived as attractive; classification method - for systematization of lingual means of attraction creation; functional analysis - to identify the role of these attractive fragments; quantitative method - to determine the frequency of these or those attractive means.

Results. We define linguistic attraction as the focus of a work on its reader (listener), which determines the reader's interest in the text, according to it the individual increases (or in its absence) interest in a particular work of art. According to our observations, the most typical means of creating the linguistic attraction of Charles Dickens's works, which make his works easily recognizable, are the following: 1) irony as the most common stylistic tool; 2) a diverse word play that encompasses sound levels, morphemes, words, bright flashes of foreign or altered units, etc; 
Ukrainian sense. 2020. ISSN 2313-4437

3) individualization of the character's speech at the level of vocabulary, grammar, creation of specific lexical-syntactic units.

Discussion. As time has proven, Charles Dickens's works have been and remain attractive to any reader. The analysis of the linguistic means of achieving this attraction indicates that they can be classified as follows: irony as the most common stylistic technique inherent in Dickens's work; a variety of words at the sound level (including rhyme), morphemes, words, phrases; individualization of the character's speech, which is accomplished through certain words or syntactic constructions. We see the prospects for further research in the analysis of the conservation or loss of the mentioned means of attraction during translation.

Keywords: attraction, word play, irony, individualization of speech. 